\title{
A comparative analysis of selected recommendations of the feng shui school of form, Alexander et al.'s pattern language, and findings of environmental psychology
}

Feng shui is a traditional Chinese art of creating a supportive living environment. Despite many research contributions on feng shui, very few verify (comparatively or experimentally) the actual effectiveness of feng shui recommendations. Even the architectural profession has never clearly defined its opinion on feng shui. This comparative analysis seeks to determine whether 118 selected feng shui school of form recommendations are consistent with the recommendations of Alexander et al.'s pattern language and with selected findings in environmental psychology. The results support this, showing that 34\% of the recommendations (or forty recommendations out of 118 in total) are consistent with pattern language and that $45 \%$ (or fifty-three recommendations) are fully or partially consistent with the findings of environmental psychology. Altogether, more than half of the recom- mendations (57\%, or sixty-seven recommendations) are consistent (indirectly confirmed) by one or the other knowledge system, which means that it is very likely that these recommendations will actually have the promised impact on users of physical space. Twenty-seven feng shui recommendations (or $23 \%$ out of the 118) are doubly consistent, of which most are related to the five-animals feng shui model, the importance of the presence of water and natural light in the living environment, and the importance of the main entrance. The bulk of the recommendations, which remain unaddressed, relate to the Chinese concept of living energy, or qi.

Keywords: Feng shui, Alexander's pattern language, environmental psychology, comparative analysis 


\section{Introduction}

Feng shui is a traditional Chinese art of environmental design that is supposed to support the user as much as possible. It is rooted in traditional Chinese philosophy and tightly embedded in the Chinese cultural and historical framework. It has been present in China and other Asian countries for millennia, but it has been known in the West only since the late nineteenth century. At the turn of the millennium, it experienced its first major peak of Western popularity, but the architectural profession never clearly defined its opinion on the phenomenon of feng shui. One reason for this is certainly the feng shui research barriers that Western researchers are particularly exposed to: the diversity of feng shui schools, methods, and techniques, a lack of knowledge of the language and cultural background, the subjectivity of interpreting recommendations, and, above all, the problem of isolating feng shui effects and, consequently, their scientific validation. Feng shui was first the subject of anthropological research in the West (e.g., De Groot, 1897; Needham, 1956; Freedman, 1968; March, 1968; Feuchtwang, 1974) as one of many traditional Chinese divination techniques that have been an important social phenomenon throughout Chinese history (Kubny, 2008). The techniques have evolved throughout history, from a privileged practice reserved for high society to a practice intended for everyday use and the common man (Bruun, 2003, 2008). At the same time, they evolved from a rather passive technique, the primary purpose of which is accident prevention, to an active practice, the primary purpose of which is to ensure happiness. Feng shui is closely linked to traditional Chinese philosophy and Chinese popular religion, representing an extensive collection of ideas, practices, rituals, and ceremonies connected with life cycles that connect the ordinary Chinese farmer with the local environment and society. At the same time, popular religion also extends beyond the concrete material world into the world of spirits, ancestors, and local gods, where feng shui is largely defined through the cult of ancestor worship and the cult of worshipping nature as a living being.

In addition to contemporary anthropological research (e.g., Hwangbo, 1999; Bruun, 2003, 2008; Paton, 2013), the most interesting areas of contemporary study of feng shui are the comparison between feng shui and sustainable construction (e.g., Yoon, 1980; Dan, 1994; Han, 2001; Xu, 2003; Chen \& Nakama, 2004) and the study of traditional buildings and urban arrangements (built in accordance with feng shui recommendations; e.g., Nemeth, 1987; Xu, 1998; Kalland, 1999; Thongkamsamut \& Buranakarn, 2007; Chiang, 2009; Mak, 2014; Gray, 2017). Feng shui-related contributions in contemporary architecture and urbanism are fewer than one would expect, given the active use of feng shui in the Asian world. There are significantly more professional manuals (e.g., Bramble, 2003; Mak \& So, 2009, 2011), in which architects seek to explain to fellow architects the basic principles of feng shui. At the same time, the content in research articles under various headings is very repetitive. Nonetheless, in the Asian world, feng shui is an important cultural moment whose influence can be traced through contributions in economics and real estate (e.g., Choy et al., 2007; Chang, 2009; So, 2009; Chang \& Lii, 2010; Wu et al., 2012; Yau, 2012; Chen et al., 2015), tourism (e.g., Hobson, 1994; Poulston, 2009; Poulston $\&$ Bennett, 2012), and traditional and official medicine (e.g., Whedon, 2000; Schumm, 2004; Sit, 2004; An, 2014). There are very few contributions that focus on evaluating feng shui recommendations and exploring whether these recommendations actually work, or whether they are merely part of anthropological cultural heritage. Only sixteen were identified in a literature review. They can be divided into comparative studies and field experiment studies. In the comparative studies, the effectiveness of feng shui recommendations (especially those of the feng shui school of form) is not directly tested in field research, but it is compared with findings in other fields, notably environmental psychology and contemporary architectural practice. Even in experimental studies, the main focus is on exploring the effectiveness of the school of form, and only in two cases also on parts of the school of compass (Bazley et al., 2016; Charles et al., 2017). As many as half of the field studies deal with the position of the building in the wider environment (e.g., Han \& Amita, 1996; Lynch, 2003; Han, 2004; Mak et al., 2005; Um, 2009), and half focus on the design of the building or its interior (e.g., So \& Lu, 2001; Mak et al., 2005; Poulston \& Bennett, 2012; Octavia \& Gunawan, 2014; Bazley et al., 2016; Charles et al., 2017; Hong et al., 2017; Mak, 2017). Some studies seek to prove the credibility of feng shui recommendations through existing evaluation systems (see, e.g., Chang et al., 2009; Pheng et al., 2012). However, the comparative studies by Bonaiuto et al. (2010) and $\mathrm{Xu}$ (2004) are of particular interest for the comparative analysis performed, and in both cases the feng shui school of form is at the forefront.

In a comparative study of selected elements of environmental psychology and feng shui, Bonaiuto et al. (2010) first introduced the two disciplines in terms of their core characteristics and fields of activity. What follows is a rough comparative analysis between the two, determining that many findings of environmental psychology are embedded in feng shui design recommendations. Two properties of the physical space are analysed in detail: the restorative element and the control element. Restorative elements of the environment reduce mental fatigue and stress (e.g., a view of water or nature). Control reflects the level of power over the environment, and its lack is often associated with stress. Both elements are recognized as 
very important environmental features that support wellbeing in both disciplines. The study concludes that there are points of contact between environmental psychology and feng shui. The disadvantage of the study is that, when presenting feng shui, it focuses solely on the concepts of the school of form and does not even mention the compass school. Xu (2004) analyses the theoretical foundations of feng shui and compares them to the basic human needs of behavioural psychology: survival, safety, sexuality, and development. The author notes that architects should incorporate key findings of feng shui theory in creating architectural solutions. The basis for the comparative analysis between the selected recommendations of the school of form, environmental psychology, and Alexander et al.'s pattern language, which is presented below, was made in the framework of the master's thesis Feng shui: primerjalna študija izbranih tradicionalnih priporocil in sodobnih dognanj (Feng Shui: A Comparative Study of Selected Traditional Recommendations and Contemporary Findings; Kryžanowski, 2012) at the University of Ljubljana's Faculty of Architecture. Based on the results, the following research question should be answered: "Are the selected recommendations of the feng shui school of form consistent with the findings of the selected chapters of environmental psychology and pattern language in the sense that their spatial (or design) or psychological impact on the user is the same?"

\section{Methods}

A comparative analysis is performed using the descriptive scientific method (Kališnik \& Lah, 1998), in which the researchers do not influence the phenomena or information studied, but only analyse this. First, a database of feng shui recommendations was created, and afterward two separate comparisons were made: first, between the feng shui database and Alexander et al.'s pattern language, and then with the findings of environmental psychology.

\subsection{Creation of the feng shui school of form recommendations database}

The feng shui school of form was taken as the starting point for the creation of the feng shui recommendations database. There are two major schools of feng shui: the school of form and the compass school. The school of form is more intuitive, and the compass school is more mathematical. The basic starting point of the school of form is the presence of the life force qi in the landscape and the corresponding ideal positioning of new buildings or cities. It is very important to take into account the five-animals model (also known as four emblems) or the five feng shui geographical secrets (e.g., Mak, 2014). In contemporary Western interpretations of feng shui, the focus of the school of form recommendations has shifted from the placement of the building in the landscape to the recommendations regarding interior design, but the basic logic remains the same. The compass school is more repetitive and mathematically modelled then the school of form. As the name implies, the main instrument used by the compass school is the compass. The Chinese already knew in the first century AD that the magnetic field has an effect on living beings (Kubny, 2008: 251). Further logical reasoning was that the magnetic field also affects humans. The magnet's needle, following the principle of "equal attracts equal", is supposed to be capable of showing the flow of Earth's qi because it was magnetized directly with Earth's qi. The feng shui compass school developed different techniques for calculating what the quality of qi should be in specific areas of physical space relative to the compass directions based on the magnetism of the Earth (the impact of the Earth) and at specific time intervals based on the influence of celestial bodies (the impact of the sky).

From the above outline of the two schools and an in-depth analysis of their recommendations, it is clear that only the school of form could be chosen for comparative analysis with contemporary findings. Its recommendations are similar in structure (but not necessarily in content) to those of environmental psychology and pattern language. All three systems describe spatial situations and evaluate whether people feel comfortable or less comfortable when faced with them. On the other hand, it is not clear what could be used for a comparison of the recommendations of the compass school. In contemporary architecture and urbanism (or other fields of science), there is no system that works in the same or at least roughly the same way - in the sense that the degree of comfort in a room or spatial arrangement would be judged primarily according to the compass orientation, the year of the completion of the building, or the user's birthday. The compass school could be scientifically evaluated only by using the experimental method.

The first step, therefore, was to create a database of feng shui school of form recommendations (2011) based on the study of relevant feng shui manuals, information received through education (training for a feng shui consultant), and the author's own (then fifteen years') practical experience in feng shui consulting. Neither then nor today was there a consensus among feng shui researchers on which of the many methods and techniques actually belong to traditional feng shui. One cannot say that there is a unified database of traditional feng shui knowledge because over history many variations of individual techniques developed, which are not always harmonized. An additional problem is that the recommendations form part of traditional knowledge and are stated in the texts without any specific scientific justification regarding their effectiveness. 
Therefore, the creation of the database of the school of form recommendations is based on an in-depth study of the literature, on the works of authors that identify themselves as teachers of traditional feng shui (as opposed to the new age commercial feng shui of "life stations"), and whose recommendations are the same or at least very similar. Selected authors include Joseph Yu (Moran et al., 2005), Ewa Wong (1996, 2001), Derek Walters (Volters, 1998), and Evelin Lip (1979, 1986, 1994). The recommendations of Jes Tyng-Yee Lim $(1997,2000)$ are also partially incorporated, but without the recommendations for commercial feng shui techniques. The database excludes all recommendations related solely to the Chinese cultural and historical framework (e.g., the use of Chinese symbols, decorations, or mirrors), recommendations that do not have a direct design impact, and recommendations that cannot be linked to the philosophical background in which feng shui is grounded. The selected authors have only a few or no such recommendations. For the purpose of constructing the feng shui database, the recommendations are first summarized in the form of a text (manual) and divided into several chapters (e.g., the concept of qi in a landscape; the five-animals model; and recommendations for the bedroom, kitchen, office space, and so on). For the sake of the comparative analysis, the recommendations of the school of form are next summarized in a database of 118 simple claims and divided into two sections: the landscape with the building's surroundings and the building itself with interior design (part of the recommendations are presented in Tables 1 and 2).

\subsection{Creation of Alexander et al.'s pattern language database}

In the second step, recommendations from pattern language were analysed (Alexander et al., 1977). Alexander et al. claim that certain spatial situations support life, whereas others do not. With each of the patterns, they identify one of the problems in the environment and propose an appropriate solution. The patterns move from the level of the region, through the level of the settlement, to the level of the surrounding area of the building, the building itself, the individual rooms in the building, and at the end the construction details. Each pattern has a comprehensive description of the problem and possible comparisons with findings in other fields of science. Each pattern ends with instructions on how to design the physical space to eliminate the problem identified in the introduction. All 253 patterns work together as a whole (one organism), which is a crucial point for Alexander et al. Some patterns are very similar and appear only on different scales (e.g., a square, yard, or living room).

For the purposes of the comparative analyses, all patterns identified by Alexander et al. and all feng shui recommendations were compared. The comparison was based on a list of 118 feng shui school of form recommendations. The basic starting point of the comparison was whether the recommendations have the same or a very similar effect: in terms of urban design (e.g., desirable presence of natural landscape near or in close proximity to buildings), in terms of the design of individual elements of a building (e.g., windows in all rooms of the structure), or in terms of the psychological effect on the user (e.g., proximity to water has a positive effect on human wellbeing). If the effect was identified as being the same or similar, in a way that it could be described through one statement compliant with the basic message of both recommendations, it was marked Yes. In doing so, the level of compliance described by $Y e s$ was classified into three levels. If the recommendations were the same in the sense that they used the same words for the same concepts (e.g., main entrance) and were describing the same number of parameters (e.g., clearly visible or illuminated), the mark Yes was used. If the essence of the two recommendations was the same but the vocabulary used was different, it was marked (Yes). The same marking (Yes) was also applied when the recommendations used the same vocabulary, but one recommendation included several parameters and the other recommendation included only some of these parameters. If the vocabulary used was different and the consistency of the meaning can be ascertained only through logical derivation using induction or deduction and, at the same time, one recommendation may include several parameters and the other one only part of them, the mark ((Yes)) was used. In short, Yes indicates a high degree of compliance, (Yes) partial compliance, and $((Y e s))$ indirect compliance. If none of Alexander et al.'s patterns could be identified for the school of form recommendation, a pattern that is comparable either in effect or in essence, the field denoting the degree of compliance remained blank. In some cases, the pattern from pattern language has a directly opposite recommendation from the school of form. There were not many of these cases, but they are marked $N o$ in Table 1. Table 1 shows all four levels of compliance described above, together with a substantive essence statement that is common to both recommendations.

\subsection{Creation of the database according to environmental psychology recommendations}

For the purpose of comparative analysis, the findings of environmental psychology have been summarized according to content; for example, recommendations for home design, the work environment, retail, and so on. Two works have been taken as a basis. Place Advantage (Augustin, 2009) offers current research findings in environmental psychology, and Environmental Psychology (Bell et al., 2001) on its general character- 
Table 1: Examples of the school of form recommendations and their comparison with Alexander et al's pattern language.

\begin{tabular}{|c|c|c|c|}
\hline School of form recommendation & $\begin{array}{l}\text { Recommendation or part of it from Alexander et al's } \\
\text { pattern language }\end{array}$ & Substantive essence & Compliance \\
\hline \multirow{10}{*}{$\begin{array}{l}\text { 3. The location of the building or spa- } \\
\text { tial arrangement is favourable when } \\
\text { it takes into account (the five-animals } \\
\text { model): protected back, partially } \\
\text { protected left and right sides of the } \\
\text { building, or spatial arrangement and } \\
\text { open space in front (without objects) } \\
\text { with a view. }\end{array}$} & $\begin{array}{l}\text { 96. (part) The height of the building should not differ } \\
\text { significantly from the neighbouring buildings. }\end{array}$ & \multirow{10}{*}{$\begin{array}{l}\text { The space should be } \\
\text { - designed in such a way } \\
\text { that it gives a feeling of } \\
\text { at least partial protection } \\
\text { and the possibility of } \\
\text { looking at (controlling) } \\
\text { the larger open space. }\end{array}$} & \multirow{10}{*}{ Yes } \\
\hline & $\begin{array}{l}\text { 106. (part) All open spaces should be designed in a } \\
\text { way to have at least a partial sense of protection. }\end{array}$ & & \\
\hline & $\begin{array}{l}\text { 114. In an open space, people always look for a place } \\
\text { where they have a protected back and a view of the } \\
\text { larger open space. }\end{array}$ & & \\
\hline & $\begin{array}{l}\text { 115. (part) The inner courtyard should have a view of } \\
\text { the larger open space. }\end{array}$ & & \\
\hline & $\begin{array}{l}\text { 124. (part) Life in the public square is shaped along } \\
\text { the edges, which allows for protection and lingering. }\end{array}$ & & \\
\hline & $\begin{array}{l}\text { 125. (part) In an open space with an activity, the most } \\
\text { interesting areas for lingering are those that are sligh- } \\
\text { tly elevated and allow for both control of the surroun- } \\
\text { dings and involvement in activities. }\end{array}$ & & \\
\hline & $\begin{array}{l}\text { 126. (part) Somewhere in the middle of a large open } \\
\text { public space, there should be a tree, fountain, or other } \\
\text { feature where people can protect their backs. }\end{array}$ & & \\
\hline & $\begin{array}{l}\text { 183. In a good working space, a wall should be at } \\
\text { least behind the back and on one side, while the front } \\
\text { should open into a larger area. }\end{array}$ & & \\
\hline & $\begin{array}{l}\text { 185. (part) The seating area should be protected, } \\
\text { without crossing paths, and in an approximately semi- } \\
\text {-circular shape. }\end{array}$ & & \\
\hline & $\begin{array}{l}\text { 193. Every space should have a balance between } \\
\text { openness (flowing space) and closedness (cell space). }\end{array}$ & & \\
\hline
\end{tabular}

107. People are more positive in buildings with win-

dows than in buildings without windows. Light plays a key role in maintaining circadian body rhythms.

38. Through the windows and doors, the vital energy qi enters the object.
62. Narrow corridors with blind ends are uncomfortable.
128. The main living quarters should face south. Sun-

\section{Place the building in an ideal loca-} tion with respect to the flow of life energy qi in the landscape. shine in the living room is of utmost importance for living quality.

192. Rooms without a view (without windows) adversely affect living quality.

\section{The corridors should be short, spacious, and} preferably illuminated.

132. The corridors should be spacious so that furniture wide enough. The corridors should be can also be fitted, creating a sense of living.

(Yes)

104. Buildings must be placed in the worst locations in the landscape, not the best.
The presence of windows in the room has a positive effect on living conditions.

\section{A road or river should always be in the front of the building, not in the back, because the dynamic energy flow weakens the back.}

Note: Yes = high compliance; (Yes) = partial compliance; $(($ Yes $))=$ indirect compliance; No = reverse effect of recommendation; blank = no compliance. Source: author. 
Table 2: Examples of the school of form recommendations and their comparison with environmental psychology findings.

\begin{tabular}{|c|c|c|c|}
\hline School of form recommendation & $\begin{array}{l}\text { Recommendation or part of it from environmental } \\
\text { psychology }\end{array}$ & Substantive essence & Compliance \\
\hline \multirow{6}{*}{$\begin{array}{l}\text { 106. The ideal workplace has a } \\
\text { protected back, space control, } \\
\text { the ability to look through the } \\
\text { window, and the possibility of } \\
\text { viewing the door. }\end{array}$} & $\begin{array}{l}\text { In the workplace (when working) people want to have } \\
\text { a protected back (Augustin, 2009: 198), while also } \\
\text { controlling the access to the room (Augustin, 2009: } \\
\text { 29). }\end{array}$ & \multirow{6}{*}{$\begin{array}{l}\text { The best seating areas are } \\
\text { places with a protected back, } \\
\text { with the possibility of looking } \\
\text { at a larger open space, and } \\
\text { with access control. }\end{array}$} & \multirow{6}{*}{ Yes } \\
\hline & $\begin{array}{l}\text { People want to have something solid (a wall or parti- } \\
\text { tion) behind their back while sitting (Augustin, 2009: } \\
\text { 72). }\end{array}$ & & \\
\hline & $\begin{array}{l}\text { Due to "prehistoric memory", we like to sit with a } \\
\text { protected back facing open space (Augustin, 2009: } \\
10,85 \text { ). }\end{array}$ & & \\
\hline & $\begin{array}{l}\text { We like to sit in rooms that give a sense of shelter } \\
\text { with lower ceilings and a view of the larger open spa- } \\
\text { ce (Hildebrandt, 1999, cited in Augustin, 2009: 11). }\end{array}$ & & \\
\hline & $\begin{array}{l}\text { Children and adults are more relaxed and learn more } \\
\text { easily when they are in a room that is protected and } \\
\text { has preferably a slightly lower ceiling (Augustin, 2009: } \\
\text { 228). }\end{array}$ & & \\
\hline & $\begin{array}{l}\text { We love rooms that allow us to control access (Augu- } \\
\text { stin, 2009: 29). }\end{array}$ & & \\
\hline \multirow{9}{*}{$\begin{array}{l}\text { 1. From natural landscapes, the } \\
\text { life energy qi enters the building }\end{array}$} & $\begin{array}{l}\text { The presence and possibility of a view of the natural } \\
\text { landscape next to the building has a positive impact } \\
\text { on living quality. It promotes psychological and physi- } \\
\text { cal health (Augustin, 2009: 234). }\end{array}$ & \multirow{9}{*}{$\begin{array}{l}\text { The proximity of natural green } \\
\text { areas (or the possibility of a } \\
\text { view of green areas) has a } \\
\text { beneficial effect on wellbeing } \\
\text { in buildings. }\end{array}$} & \multirow{9}{*}{ (Yes) } \\
\hline & It allows for: & & \\
\hline & $\begin{array}{l}\text { - A restorative effect (Kaplan, 1995, cited in Augustin, } \\
\text { 2009: 31); }\end{array}$ & & \\
\hline & $\begin{array}{l}\text { - The reduction of mental exhaustion and stress in } \\
\text { lecture rooms (Augustin, 2009: 223); }\end{array}$ & & \\
\hline & $\begin{array}{l}\text { - Mental refreshment in shopping malls (Augustin, } \\
\text { 2009: 219); }\end{array}$ & & \\
\hline & $\begin{array}{l}\text { - More satisfaction with a job (Edwards, 2008, cited in } \\
\text { Augustin 2009: 186); }\end{array}$ & & \\
\hline & $\begin{array}{l}\text { - A positive impact on home and job wellbeing (Ka- } \\
\text { plan, 1993, 2001, cited in Augustin, 2009: 186); }\end{array}$ & & \\
\hline & $\begin{array}{l}\text { - Reduced stress and a re-established higher level of } \\
\text { mental energy in hospital environments (Ulrich, } 1984 \\
\text { and Ulrich et al., 1991, cited in Augustin, 2009: 231); }\end{array}$ & & \\
\hline & $\begin{array}{l}\text { - Generally improved wellbeing and effectiveness } \\
\text { when in the presence of plants (Augustin, 2009: 34). }\end{array}$ & & \\
\hline $\begin{array}{l}\text { 28. A building near hospitals, } \\
\text { cemeteries, slaughterhouses, and } \\
\text { other places related to disease, } \\
\text { torture, or death is unfavourable. }\end{array}$ & $\begin{array}{l}\text { People are attracted to places that promise comfort, } \\
\text { safety, and a sense of appreciation (Augustin, 2009: } \\
\text { 14). }\end{array}$ & $\begin{array}{l}\text { People are not attracted to } \\
\text { places associated with illness, } \\
\text { torture, or death. }\end{array}$ & $(($ Yes $))$ \\
\hline
\end{tabular}

25. When on a slope, the entrance to the building should be on the lower side.

Note: Yes = high compliance; $($ Yes $)=$ partial compliance; $(($ Yes $))=$ indirect compliance; blank = no compliance. Source: author.

istics. Based on the same methodology used in comparative analyses with Alexander et al's pattern language, each of the 118 feng shui recommendations were attributed a degree of compliance: Yes high, (Yes) partial, ((Yes)) indirect, or blank, which means there was no consistency between the recommendations of the feng shui school of form and the findings of environmental psychology. Table 2 shows all four of these levels of compliance together with the substantive essence statement common to both recommendations. 


\section{Results and discussion}

\subsection{Comparison of selected feng shui recommendations and Alexander et al.'s pattern language}

Analysis of the comparison between 118 of the feng shui school of form recommendations and Alexander et al.'s pattern language shows that for twenty-one feng shui recommendations it is possible to find a pattern demonstrating high compliance with the feng shui recommendation (marked Yes), fourteen feng shui recommendations are partially compliant with Alexander et al's pattern language (marked $(Y e s))$, and five recommendations are linked via indirect compliance (marked $((Y e s)))$. Altogether, at least a minimum level of compliance can be detected in forty recommendations, representing 34\% of all feng shui recommendations. In this, recommendations with contrary effect, although dealing with the same or similar content, are not taken into account (e.g., see Recommendation 2 in Table 1). Taken together, such recommendations number five ( $4 \%$ of all recommendations). Two of them are conditionally inconsistent with pattern 116, which speaks of the need for cascading roofs. Namely, feng shui has reservations against sharp edges of roofs that can point into living quarters, and the number of these, in the case of a highly structured roof with several levels, is higher. In the structure of the levels of compliance, it stands out that the most recommendations are linked through a high degree of compliance, where the same vocabulary is used in addition to the same spatial impact. The second highest is the share of indirect compliance with the same substantive essence and spatial effects, but different vocabulary. This was expected. The feng shui recommendations as well as Alexander et al.'s patterns cover spatial situations in the urban environment or in buildings and therefore use the same terminology (e.g., both discuss the importance of the presence of water in the open spaces or the importance of a well-designed main entrance).

Looking more precisely at the feng shui recommendations that are indirectly, partially, or very compliant, it turns out (see Table 3) that they are by far most associated with the five-animals model (twelve recommendations, or 30\%), followed by the importance of natural lighting and the presence of windows (four recommendations, or 10\%) and finally the importance of water and the main entrance (each has three recommendations, or $7.5 \%$ ). Five per cent of the samples (or two patterns per recommendation) are linked to green areas, roads and crossings, sharp edges and corners, and the importance of the bed. All remaining patterns can be associated with only one feng shui recommendation, which represents an individual residual of $2.5 \%$.
I also wondered what portion of all 253 of Alexander et al.s patterns is covered by the selected 118 feng shui school of form recommendations. Forty feng shui recommendations, which are compliant in various degrees, represent 16\% (of a total of 253) of all patterns. An additional five recommendations (2\%) are compliant with Alexander et al's patterns, but the effect of these is exactly reversed. Depending on the total number of patterns, the overlap rate is low. One of the reasons for this is that Alexander et al.'s patterns have an exceptionally wide spectrum that goes from the level of the region ( $40 \%$ of patterns), through the level of the building (40\%), to the construction level (20\%). In the case of selected feng shui recommendations, most (77\%) deal with the building and its interior design, and only $33 \%$ are left for the region, construction, and building details. In terms of the research question examined, based on the first part of the comparative analysis, among 118 feng shui school of form recommendations, forty (34\%) are indirectly, partially, or highly compliant with the recommendations of Alexander et al.s pattern language.

\subsection{Comparison of selected feng shui recommendations and the findings of environmental psychology}

Analysis of the comparison between 118 feng shui school of form recommendations and the findings of environmental psychology reveals that twelve feng shui recommendations are highly compliant with environmental psychology findings (marked Yes), eighteen of the feng shui recommendations are partially compliant with environmental psychology (marked $(Y e s))$, and as many as twenty-three recommendations are indirectly compliant (marked $((Y e s)))$. Taken together, at least a minimum level of compliance can be defined for fifty-three recommendations, accounting for $45 \%$ of all 118 feng shui recommendations. In contrast to Alexander et al's pattern language, the highest share of compliance is that of indirect and partial compliance. This can be explained by the fact that, contrary to pattern language, the findings of environmental psychology (in the sources considered) are presented primarily through general rules explaining people's responses to selected spatial elements or arrangements. Through examples, responses to particular situations are also explained, but in less detail than in Alexander et al's pattern language or feng shui.

A detailed analysis of all compliant, partially compliant, and indirectly compliant feng shui recommendations (see Table 4) shows that $32 \%$ are related to the need for shelter and control, or to the five-animals model, as referred to in the school of form. Many recommendations are associated with non-verbal communication of physical space or with psychological attraction of spatial arrangements (24\%). Most of these recommen- 
Table 3: Comparison of individual feng shui themes and Alexander et al.'s patterns.

\begin{tabular}{lll}
\hline Themes of feng shui recommendations & Sequence number of patterns & Share as $\%$ of $40^{*}$ \\
\hline Five-animals scheme & $90,96,105,106,114,115,124,125,126,183,185,193$ & 30 \\
\hline Natural lighting, the meaning of the window & $107,128,192,194$ & 7.5 \\
\hline The importance of water & $25,64,71$ & 7.5 \\
\hline Main entrance and front lobby & $110,112,130$ & 5 \\
\hline Green areas and natural landscapes & 3,60 & 5 \\
\hline Roads and crossings & 49,50 & 5 \\
\hline Sharp corners and edges & 116,191 & 5 \\
\hline Bed & 187,188 & 2.5 \\
\hline Correct shapes, order, symmetry & 99 & 2.5 \\
\hline ldeal location & 104 & 2.5 \\
\hline Garage & 113 & 2.5 \\
\hline Roof & 117 & 2.5 \\
\hline Empty centre & 129 & 2.5 \\
\hline Corridors & 132 & 2.5 \\
\hline Stairs & 133 & 2.5 \\
\hline Bathroom & 144 & 2.5 \\
\hline Workplace & 183 & 2.5 \\
\hline Kitchen & 184 & 5 \\
\hline
\end{tabular}

Note: *The share for the individual feng shui theme is based on the number of Alexander et al.'s patterns that overlap with this theme. Source: Kryžanowski (2012: 175).

Table 4: Comparison of environmental psychology themes and the share of the feng shui recommendations linked to these themes.

\begin{tabular}{lll}
\hline Environmental psychology themes & $\begin{array}{l}\text { Link to feng shui recom- } \\
\text { mendations }\end{array}$ & Share as \% of 53 \\
\hline $\begin{array}{l}\text { The need for shelter (safety) and control (view of a larger open space), control of access } \\
\text { to the room, and the impact of prehistoric memory on responses to physical space }\end{array}$ & $\begin{array}{l}3,41,42,65,78,83,86,91, \\
94,106,107,108,109,110,232 \\
111,113,114\end{array}$ \\
\hline $\begin{array}{l}\text { Psychological attraction/non-attraction of arrangements (nonverbal communication and } \\
\text { first impression) }\end{array}$ & $\begin{array}{l}28,30,31,36,40,44,45, \\
67,68,77,92,102,105\end{array}$ & 24 \\
\hline Impact of form, patterns (sharp, aggressive, correct, symmetry, stability), and colour & $\begin{array}{l}26,27,35,37,46,63,71, \\
72,73,74\end{array}$ & 19 \\
\hline Presence of natural light (presence and position of the window, glare) & $32,38,95,98,112$ & 9.5 \\
\hline Presence of water elements & $15,17,34,43,99$ & 9.5 \\
\hline View of nature (especially restorative effect) & 1,11 & 4 \\
\hline Impact of wind & 5 & 2 \\
\hline
\end{tabular}

Source: author.

dations show indirect compliance (nine out of thirteen). Next are the influences of form, patterns, and colours (19\%), where the negative impact of sharp and aggressive forms, emphasized in feng shui, is predominant. This is also confirmed by the findings of environmental psychology, but it is not specifically stressed. The remaining feng shui recommendations are linked to the impact of natural elements (light, water, nature, and wind) and together comprise the remaining quarter of all recommendations. A more detailed overview of the shares associated with the environmental psychology themes is provided in Table 4.
In terms of the research question, the comparative analysis of the feng shui school of form and environmental psychology showed that, out of 118 feng shui school of form recommendations, fifty-three (45\%) are indirectly, partially, or highly compliant with the findings of environmental psychology.

This means that, based on the findings of environmental psychology, one could conclude that a good $45 \%$ of the feng shui school of form recommendations presented in this article have actual positive effects on wellbeing in the physical space. To analyse the effectiveness of the remaining 55\%, the same 
strictly controlled studies should be carried out as outlined in the research protocols of environmental psychology. It would also be interesting to examine what portion of the findings of environmental psychology as a whole is actually covered by the selected feng shui recommendations. The influential area of environmental psychology is significantly broader than the segment focusing on wellbeing, and the method used is not appropriate for this purpose. In any case, it can be concluded that the school of form as a whole covers only a small fraction of the area otherwise studied by environmental psychology, even though the school of form recommendations can be applied from the level of urbanism down to the level of interior design.

\section{Conclusion}

Based on the results of the comparative analyses, the answer to the research question is affirmative in both cases. The combined comparison of the compliant recommendations (of all three types) according to one or the other of the two analyses further shows that Alexander et al.s patterns and the findings of environmental psychology do not cover the same feng shui recommendations. As a whole, sixty-seven feng shui recommendations are compliant, which is just over half (57\%) of all 118 feng shui recommendations. Of these, twenty-seven recommendations have double compliance (or $40 \%$ out of sixty-seven), taking into account all three levels of compliance. This means that all three systems (feng shui, pattern language, and environmental psychology) result in the same findings or spatial recommendations. The remaining forty recommendations (or $60 \%$ out of sixty-seven) are single-compliant, which means that these feng shui recommendations are either compliant with pattern language or with the findings of environmental psychology. For just over half of the selected 118 feng shui recommendations, it can therefore indirectly be concluded that there is a high likelihood that these recommendations actually have the impact on the users that they promise.

Of the double-compliant feng shui recommendations, just under half (twelve) can be linked to the feng shui five-animals model. Apparently, this traditional Chinese model has managed to identify one of the driving factors for human wellbeing in physical space. The five-animals model can also be connected to the ideal state of things in the sky because the model basically comes from cosmology (Field, 2006) and symbolizes the constellations in the sky. In feng shui the abstract astrological diagram is transformed into a practical spatial model useful in urbanism and architecture as well as in interior design. As for the natural elements, the presence of natural landscapes, natural light, and water is very important for wellbeing. According to feng shui, water is supposed to accumulate qi. It is important for human wellbeing in physical space, and it is also highlighted in the recommendations of environmental psychology and Alexander et al.'s theory. In terms of architectural elements, the building's main entrance is definitely an important issue. It represents the point of transition between the outside and the inside, and as a rule it is the main point of orientation on the façade and the first thing people come into direct contact with when facing the building. Its significance for the subjective experience of the building is therefore highlighted in all three strands of knowledge. It can be summarized that, when talking about compliant feng shui recommendations, this is first and foremost a discussion about the basic rules of design and of behaviour in physical space, conditioned by basic psychological reactions to spatial arrangements, which are (and were repeatedly) discovered by all cultures and traditions, and are introduced into urban and architectural design in accordance with the current state of the art and needs.

Feng shui recommendations that remain unreferenced can be classified into two categories. The first refers to the living energy qi and its behaviour in physical space, and the second is a conglomerate of various recommendations that cannot be unified under a single label. The concept of the life force qi, as expected, is not a topic that one or the other set of contemporary knowledge would consider, and so compliance was not even expected. It is important to emphasize the need for more intensive research into the effectiveness of feng shui recommendations and for the development of models that allow for an objective evaluation of both the school of form and the compass school (e.g., Kryžanowski, in press). From this kind of scientific exploration of feng shui, both modern science and feng shui can only benefit. In this way, this fascinating traditional system of knowledge can be refined and begin to move from the field of pseudoscience into the field of science. At the same time, verified feng shui recommendations can be integrated into the concepts of modern design practice in a controlled manner. After all, comparative analysis shows that a good half of the feng shui recommendations under consideration either claim or recommend the same thing as environmental psychology or Alexander et al.s pattern language. If models were developed to effectively validate the part of feng shui that addresses concepts that modern design practices know nothing about, it would be possible to replace the mere search for similarities between the two with constructive complementation.

\section{Špela Kryžanowski}

Faculty of Design, Independent Higher Education Institution, associate member of the University of Primorska, Trzin, Slovenia E-mail: spela.kry@gmail.com 


\section{Acknowledgements}

This article contains findings obtained while preparing my master's thesis and dissertation, and I therefore thank my advisor Janez Koželj and co-advisor Marko Polič (Kryžanowski, 2012), and my advisor Igor Jerman and co-advisor Karmen Medica (Kryžanowski, in press) for their support.

\section{References}

Alexander, C., Ishikawa, S., Silverstein, M., Jacobson, M., Fiksdahl-King, I. \& Angel, S. (1977) A pattern language. New York, Oxford University Press.

An, S. (2014) A case study on hospital interior colour design reflecting feng shui. Journal of the Korean Society of Colloid Science, 28(3), pp. 8192 (in Korean).

Augustin, S. (2009) Place advantage. Hoboken, NJ, Wiley\&Sons.

Bazley, C., Vink, P., Montgomery, J. \& Hedge, A. (2016) Interior effects on comfort in healthcare waiting areas, Work, 54(4), pp. 791-806.

Bell, A. B., Green, T. C., Fisher, J. D. \& Baum, A. (2001) Environmental psychology. Mahwah, NJ, Lawrence Erlbaum Associates.

Bonaiuto, M., Bilotta, E. \& Stolfa, A. (2010) Feng shui and environmental psychology: A critical comparison. Journal of Architectural and Planning Research, 27(1), pp. 23-34.

Bramble, C. (2003) Architect's guide to feng shui. Oxford, Architectural Press.

Bruun, O. (2003) Feng shui in China: Geomantic divination between state orthodoxy and popular religion. Honolulu, University of Hawaii Press.

Bruun, O. (2008) An introduction to feng shui. Cambridge, Cambridge University Press.

Chang, W. L. (2009) Using feng shui to create a positive corporate reputation. Corporate Reputation Review, 12(1), pp. 43-51.

Chang, W. L. \& Lii, P. (2010) Feng shui and its role in corporate image and reputation: A review from business and cultural perspectives. Journal of Architecture and Planning Research, 27(1), pp. 1-13.

Chang, P. T., Lee, J. H., Hung, K. C., Tsai, J. T. \& Perng, C. (2009) Applying fuzzy weighted average approach to evaluate office layouts with feng shui consideration. Mathematical and Computer Modelling, 50, pp. 1514-1537.

Charles, R., Glover, S., Bauchmueller, K. \& Wood, D. (2017) Feng shui and emotional response in the critical care environment (FARCE) study. Anaesthesia, 72, pp. 1528-1531.

Chen, B. X. \& Nakama, Y. (2004) A summary of research history on Chinese feng-shui and application of feng-shui principles to environmental issues. Available at: http://ffpsc.agr.kyushu-u.ac.jp/jfs-q/kyushu_forest_research/57/57po013.PDF(accessed 25 Nov. 2019).

Chen, K. H., Chang, W. L., Chih, I. L. \& Liao, C. N. (2015) Framing the decision making model of the Chinese business with feng shui concept. Human Systems Management, 34, pp. 225-232.

Chiang, M. (2009) Feng shui design and planning of Ming and Qing city of Beijing. In: Mak, M. Y. \& So, A. T. (eds.) Research in scientific feng shui and the built environment, pp. 137-150. Hong Kong, City University of Hong Kong Press.

Choy, L. H. T., Mak, S. W. K. \& Ho, W. K. O. (2007) Modeling Hong Kong real estate prices. Journal of Housing and the Built Environment, 22(4), pp. 359-368.
Dan, H. (1994) A human-ecology approach to environmental design: An integrative human ecology design derived from Chinese agricultural culture experiences. Journal of Environmental Sciences, 6, pp. 478-486.

De Groot, J. J. M. (1897) The religious system of China. Leiden: Brill.

Feuchtwang, S. (1974) An anthropological analyses of Chinese geomancy. Bangkok, White Lotus.

Field, S. L. (2006) An overview of ancient fengshui. Available at: http:// www.fengshuigate.com/overview.html (accessed 5 Sept. 2006)

Freedman, M. (1968) Geomancy. Proceedings of the Royal Anthropological Institute of Great Britain and Ireland, 1968, pp. 5-15.

Gray, J. (2017) Domestic mandala: Architecture of lifeworlds in Nepal. London, Routledge.

Han, K. T. (2001) Traditional Chinese site selection - feng shui: An evolutionary/ecological perspective. Journal of Cultural Geography, 19(1), pp. 75-96.

Han, K. T. (2004) A preliminary study of Luan Tou feng shui landscapes and psychological reactions. Journal of Psychology in Chinese Societies, 5(2), pp. 265-289.

Han, K. T. \& Amita, S. (1996) An empirical study of feng shui in landscape. Environments, 23(3), pp. 36-49.

Hobson, J. S. P. (1994) Feng shui: Its impacts on the Asian hospitality industry. International Journal of Contemporary Hospitality Management, 6(6), pp. 21-26.

Hong, W. T., Abdul-Rahman, H. \& Wang, C. (2017) Are feng shui bedroom rules practical from the architectural perspective? In: Mak, M. Paton, M. \& Rowe, T. (eds.) Proceedings of the Academic Journal of Feng Shui. 1st Symposium - Oceania. Sydney: Oceania University of Technology.

Hwangbo, A. B. (1999) A new millennium and feng shui. The Journal of Architecture, 4, pp. 191-198.

Kalland, A. (1999) Houses, people and good fortune: Geomancy and vernacular architecture in Japan. Worldviews: Global Religions, Culture and Ecology, 3(1), pp. 33-50.

Kališnik, M. \& Lah, L. (1998) Uvod v znanstvenoraziskovalno metodologijo. Ljubljana, Univerza v Ljubljani, Fakulteta za arhitekturo.

Kryžanowski, Š. (2012) Feng shui: primerjalna študija izbranih tradicionalnih priporočil in sodobnih dognanj. Master's thesis. Ljubljana, Univerza v Ljubljani, Fakulteta za arhitekturo.

Kryžanowski, Š. (in press) Feng shui in apercepcija prostora: pregled znanstvenih prispevkov in terenska analiza učinkovitosti priporočil. Dissertation. Ljubljana, Alma Mater Europaea, Institutum Studiorum Humanitatis - Fakulteta za podiplomski humanistični študij.

Kubny, M. (2008) Feng Shui, die Struktur der Welt. Klein Jasedow: Drachen Verlag.

Lim, J. T. Y. (1997) Feng Shui und Gesundheit. Sulzberg, Joy Verlag

Lim, J. T. Y. (2000) Feng Shui für Büro und Business. Munich, Integral.

Lip, E. (1979) Chinese geomancy. Singapore, Times Books International.

Lip, E. (1986) Feng shui for the home. Singapore, Heian International.

Lip, E. (1994) Feng shui for business. Singapore, Times Books International.

Lynch, E. S. (2003) Feng shui as a site design tool: Assessing conditions of human comfort in urban places. Master's thesis. University of Arizona, Architecture and Landscape Architecture. 
Mak, M. Y. (2014) Feng shui villages in Hong Kong: A case study of Tai Fu Tai Mansion. In: Proceedings of 4th international conference on scientific feng shui and built environment 2009 (Hong Kong 2021 February, 2009), pp. 78-93. Hong Kong: Asian Institute of Intelligent Buildings / Department of Building \& Construction, City University of Hong Kong.

Mak, M. Y. (2017) An empirical study of modern sustainable office buildings in Sydney from the feng shui perspective. In: Mak, M., Paton, M. \& Rowe, T. (eds.) Proceedings of the Academic Journal of Feng Shui. 1st Symposium - Oceania. Sydney: Oceania University of Technology.

Mak, M. Y., Ng, S. T. \& Chen, S. E. (2005) Formulating a hierarchical structure of feng shui knowledge. In: Ribeiro, F., Love, P. D. E., Davidson, C. H., Egbu, S. O. \& Dimitrijevic, B. (eds.) Proceedings of the CIB W102 2005 , international conference on information and knowledge management in a global economy: Challenges and opportunities for construction organizations, 19-20 May, Lisbon, Portugal, pp. 395-404. Salford, UK, CIB-W102.

Mak, M. Y. \& So, A. T. (eds.) (2009) Research in scientific feng shui and the built environment. Hong Kong, City University of Hong Kong Press.

Mak, M. Y. \& So, A. T. (2011) Scientific feng shui for the built environment. Hong Kong, City University of Hong Kong Press.

March, A. L. (1968) An appreciation of Chinese geomancy. The Journal of Asian Studies, 27(2), pp. 253-267.

Moran, E., Yu, J. \& Biktashev, V. (2005) The complete idiot's guide to feng shui. New York, Alpha Books.

Needham, J. (1956) Science and civilisation in China. Vol. 2: History of scientific thought. Cambridge, Cambridge University Press.

Nemeth, D. J. (1987) The architecture of ideology: Neo Confucian imprinting on Cheju Island, Korea. Berkley, University of California Press.

Octavia, L. \& Gunawan, T. (2014) Feng shui in modern house design: Searching for the rationale and possible impacts assessment. Journal of Architecture and Built Environment, 41(1), pp. 43-50.

Paton, M. (2013) Five classics of feng shui, Chinese spiritual geography in historical and environmental perspective. Leiden, Brill.

Pheng, L. S., Xiaopeng, D. \& Ting, Q. L. (2012) Assimilating total building performance mandates with Chinese geomancy principles and scenarios. Facilities, 30(13/14), pp. 558-589.

Poulston, J. (2009) Taking feng shui seriously. Available at: https:// openrepository.aut.ac.nz/bitstream/handle/10292/1628/poulston \%20 paper2 \%20- \%20feng \%20shui.pdf?sequence=2\&isAllowed=y (accessed 12 Apr. 2018).

Poulston, J. \& Bennett, R. (2012) Feng shui, fact and fiction: An exploratory study. Available at: https://www.researchgate.net/profile/Jill_Poulston/publication/235260228_Fact_fiction_and_feng_shui_An_exploratory_study/links/5669e80308ae62b05f027175/Fact-fiction-and-fengshui-An-exploratory-study.pdf (accessed 12 Apr. 2018).

Schumm, C. (2004) Feng Shui im Krankenhaus: Architektur und Heilung. Vienna, Springer Verlag.

Sit, W. (2004) Feng shui elements and life areas approach for older persons in a nursing care facility. Dissertation. Denton, Texas Woman's University.

So, C. H. (2009) An examination of the effect of feng shui on residential property price in Hong Kong. Bachelor's thesis. Hong Kong, The University of Hong Kong, Department of Real Estate and Construction.

So, A. T. P. \& Lu, J. W. Z. (2001) Natural ventilation design by computational fluid dynamics - A feng-shui approach. Architectural Science Review, 44(1), pp. 61-69.
Thongkamsamut, C. \& Buranakarn, V. (2007) Form follows feng shui. Journal of Environmental Design and Planning Nakhara, 2, pp. 37-54.

Um, J. S. (2009) Exploring spatially prioritized parameters of feng-shui from tomb footprint. International Journal of Geographical Information Science, 23(4), pp. 513-529.

Volters, D. (1998) Feng shui. Belgrade, Esotheria.

Whedon, C. A. (2000) Frames of reference that address the impact of physical environments on occupational performance. Work, 14(2), pp. 165-174.

Wu, W. Y., Yau, O. H. M. \& Lu, H. Y. (2012) Feng shui principles in residential housing selection. Psychology \& Marketing, 29(7), pp. 502-518.

Wong, E. (1996) Feng shui. Boston, Shambala.

Wong, E. (2001) A master course in feng shui. Boston, Shambala.

Xu, J. (2003) A framework for site analysis with emphasis on feng shui and contemporary environmental design principles. Doctoral thesis. Blacksburg, VA, Virginia Polytechnic Institute and State University.

Xu, P. (1998) Feng shui models structured traditional Beijing courtyard houses. Journal of Architectural and Planning Research, 15(4), pp. 271282.

Xu, Z. (2004) Geomancy theories and behaviour psychology. Journal of Hefei University of Technology. Available at: http://en.cnki.com.cn/Article_en/CJFDTotal-HFGS200402034.htm (accessed: 1. Mar. 2018).

Yau, O. H. M. (2012) The key components of feng shui and their implications for marketing. Psychology \& Marketing, 29(7), pp. 479-487.

Yoon, H. K. (1980) The image of nature in geomancy. Geo Journal, 4(4), pp. 341-348. 